\title{
Minor League Baseball Is All About Being Entertained
}

Eric J. Newman, (E-mail: enewman@csusb.edu), California State University, San Bernardino

\begin{abstract}
When attending Minor League baseball games many fans are not as interested in the baseball game as they are to the entertainment experience associated with the game. They are attending the baseball game to be entertained. Many fans don't actually watch and completely understand the baseball game; they come for the whole entertainment experience. They attend to watch the people, eat good food, drink, be around friends, feel a sense of belonging, and to watch the sports contest. The fans expect to enjoy themselves in a fun, clean, and hassle free environment. At the end of the game many fans don't really care who won the game as long as it was fun. Seventy-six percent of the fans surveyed at the ballpark said they attended the game to be entertained, but do not attend often. Minor League baseball teams play a 150 game season with 75 home games. Fifty-nine percent of the fans attend less than five games a season or seven percent of the games of the home games. Seventy-nine percent of the fans attend less than thirteen percent of the home games. The fans are not returning to the ballpark often, why? They may not be having enough fun compared with all the other entertainment choices available. There is also a limited amount of true baseball fans with only five percent of the fans attending more than half of the home games. It's time to start focusing on all those fans of entertainment, providing them opportunity to be entertained at a Minor League baseball game.
\end{abstract}

\section{INTRODUCTION}

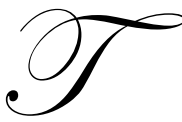

here have been many very successful entertaining movies focused on minor league baseball including hits like Bull Durham, Wild Thing, and The Natural. They show fans getting involved having fun, more fun than many viewers have ever experienced. The game of Minor League Baseball is about having fun and being entertained. Some teams are just having a harder time adapting to the changing entertainment environment.

Entertainment is defined by the Merriam Webster Dictionary as something diverting or engaging such as a public performance. The Oxford Dictionary states that to be entertained is to receive hospitality from efforts to amuse or gratify. Entertainment provides an escape that takes us away from our day to day life and problems (Bowman 1996).

The minor league baseball stadiums provide fans with the opportunity to escape the outside world. Fans are transformed into an environment controlled by Minor League baseball managers and players committed to showing the fans a good time. The Minor League Baseball experience includes a seat in the stadium to watch the athletic competition, the food, the beverages, and the team gear to enhance fan enjoyment. Minor league baseball needs to focus on providing its own entertainment because they don't have the multimillion dollar players with national headlines and endorsements.

In the beginning Minor league baseball many times was the only game in town. It's only major competition for a fan was the fans work schedule and the professional baseball team that was generally too far away. Today, on an average summer day fans have twenty-four different opportunities to watch baseball on cable television. Cable television also provides fans with three hundred and sixty other sports entertainment opportunities to watch on any given day. This doesn't include all the radio, print, and news broadcasts that are available. Fans also have access to 
one hundred and twenty other viewing opportunities per day to watch baseball and sports highlights on cable television. The fans are used to being entertained with instant replay, commentators, and even some very entertaining commercials. The fans also have access to all the area baseball games from the Little Leagues to the local high schools and colleges.

It is the responsibility of the marketers and the team to keep the fans engaged throughout the game. The engagement is important in keeping fans interested and entertained so that they will return for future games. Minor League teams like the Rancho Cucamonga Quakes and the Lansing Lugnuts have demonstrated how to integrate fun with their names and teams into every aspect of the experience. The Quakes play at the "Epicenter" with their mascot "Tremor". Now that sounds like an integrated entertainment experience.

There are still a lot of teams and management that just don't get it. They still think it is just about baseball and getting people in the seats so they will buy things. First of all Minor League Baseball players are not generally from the area in which they play. Second they are movable. The Minor League baseball players are being traded and moved up and down through the farm system. The fans don't have time to get attached to the players.

Without the individual Minor League players for marketing the team, some sports managers are adopting more of a customer service approach. Not all managers are customer service focused and differ in their marketing approach to fans. One manager complained to me about their season ticket holder's booster club. The booster club was asking for a picnic at the ball park with something other than hotdogs and his response to me was, "If you give them what they are asking for they will never quit asking for things, so I just ignore them most of the time". In general, a manager's main focus is satisfying the fan while still meeting organizational objectives (Bristow and Sebastian 2001). This is a shift from the player to business office path of the past. The marketers need the ability to think like the fans not the players. The ex-players still think it is about the game while the new marketers are realizing it is all about entertaining the fans.

The athletes work hard everyday because they love the game of baseball. The team managers have no power over the team. They can't guarantee a win or a loss and have no control of the game or its outcome. It is also about fans who love to be entertained by watching the athletes. The team managers do have power to provide the fans an entertaining experience while visiting their stadium during a baseball game. The main question is "how can we develop an entertainment venue that is not dependent on the personnel or performance of the Minor League Baseball Club that plays 75 home games in our stadium?" The next 35 games was spent talking and surveying fans to find out what they liked about Minor League Baseball.

\section{RESULTS}

The first step was to find out how many fans were returning to the ballpark to watch additional games. We surveyed over 1000 baseball fans over three different home games. Only 5\% of the fans attend more than half of the home games and this number includes the season ticket holders, perhaps there is a limited amount of true baseball fans attending the minor league baseball games. Fifty-nine percent of the fans attend less than 5 games a season or $7 \%$ of the home games. Seventy-nine percent of the fans attend less than $13 \%$ of the home games. The teams are getting the fans to the park but are not entertaining them enough to keep them coming back, which in turn is a major factor of why the stadium isn't filling with fans for the games. The fans are not motivated to return so the team is continuously looking for new fans?

If the fans are not returning to the games that is a problem. That means the team is continually looking for new fans which represents the majority of the fans. It is five times more expensive to attract a new customer to the ballpark than to keep an existing one (Sheth and Parvatiyar1995). Why aren't the fans returning to the ballpark?

The fans are not having enough fun compared with all the other entertainment choices available. The majority of the fans interviewed at the games didn't really know a lot about baseball nor did they watch much of the game. They just enjoyed visiting with friends and family and were looking to have fun. Many of the fans knew more about the promotions than the game. The fans love giveaways; it doesn't matter if it is a t-shirt or a fortune cookie. 
They love free things. They enjoy hearing music at the games and interacting with the mascot. They also like the on field promotional events, especially events with children.

Before the study the team stated that the majority of their fans were sports fans who watch a lot of professional sports. The results of the survey showed that the fans were not overwhelmingly into professional sports. The results showed that $67 \%$ of the fans surveyed don't watch professional sports. It is not the sport of baseball that they enjoy, it is the entertainment. Seventy six percent of the fans at the ballpark said they attended the game to be entertained with the majority of them not familiar with all the rules of the game. The marketers need to focus on the entertaining experience that goes along with the game as a fan of entertainment rather than just a fan of baseball.

It was intriguing to hear the minor league ball player's talk about the game compared to the fans. When the players and fans were put together in a focus group the results were different than the team mangers predicted. The managers too were past baseball players. The athletes and managers were surprised by the fans lack of caring and commitment to the game of baseball. Many of the players were surprised that the fans preferred watching a player running full steam into the outfield wall while trying to catch a fly ball than stealing a base or even stealing home plate to win the game. One fan stated "I would rather see a player in a situation that is funny and fun to watch than a serious boring game. I want to have fun!" Another fan stated "They always steal bases but running into a fence or falling down doesn't happen all the time and that's fun to watch". It's time for the teams to start focusing on and providing for the fans of "entertainment", providing them the opportunity to enjoy themselves at a Minor League baseball game.

To be successful, the minor league baseball program needs to be developed with total customer service in mind, which in turn promotes fun and entertainment. One bad experience can loose a customer for life. We watched fans who passed by a condiment table that had large puddles of ketchup and mustard on the concrete in front of the containers. The relish had already developed into a lake that fans needed to walk around. The disgusted looks on the fans faces when they walked by the condiment table told the story. We then approached many to ask their opinions. Common comments were "I lost my appetite", "Why isn't someone keeping that cleaned", "Icky". Good customer service will increase fan entertainment value which will attract more people to the Minor League Baseball games, which will increase revenues for the team (Lienert 1998).

When the fans were asked what they were going to do at the game many stated watch people "it's fun to people watch", eat, drink, be around friends, and maybe catch a foul ball. When asked why they come to the game many stated they felt as if they were a part of a large group which gives them a sense of belonging, but mainly they were looking to eat and drink. Currently sports and entertainment is the hottest market segment in on-site foodservices. Major restaurant corporations are vying to get into the sports stadiums (King 2002). It is no longer just hot dogs, peanuts, and cotton candy. Some sporting events are even offering sushi. There are no limits to what can be served at the games. Teams need to move on past the old hot dogs and peanuts and expand into whatever the fans want to buy at an affordable price and profit margin.

Seventy-six percent of the fans surveyed at the ballpark say they attended the game to be entertained with the majority not baseball fans. It should be obvious that fans just want to have fun in a clean and hassle free environment where they can relax and enjoy themselves. We were really surprised at the end of the game how many fans didn't know or really care who won the game. Many fans left before the game was over.

\section{IMPLICATIONS}

Fans want to be entertained. If they are not entertained by Minor League Baseball then they will find another opportunity from the hundreds of other choices they have to choose from. Fans are not being entertained enough because they don't return to the ball park. Their lack of attendance is not from a lack of available time. American consumers are enjoying playing more than ever before, but still not a much as many Europeans where it is illegal to work over 35 hours a week plus they have six weeks of annual leave (Elliott 2003). In the 1950's Americans were almost equal on importance of work and leisure with $44 \%$ enjoying their time at leisure away from work and $43 \%$ enjoying their time at work. In 2001, $76 \%$ of Americans enjoy their leisure time away from work with only $13 \%$ 
preferring to be at work (McLaughlin, Abraham 2001). Consumers are enjoying their time away from work and becoming more demanding and selective of their free time experiences.

Americans no longer look at leisure as time to recharge so that they can do a better job at work. They work so that they can have more leisure time (Samuelson 2001). They work hard for their leisure time and expect to enjoy themselves. They work hard and play hard. If the consumer is not entertained or satisfied at the minor league experience then they will choose another more entertaining activity from the myriad of entertainment choices available to them.

\section{CONCLUSION}

In conclusion, it is time for some of the managers to focus on customer service and customer needs. They need to focus less time on the game of baseball which they have no control over and stop ignoring the entertainment value they can provide to the fans captured in their stadium. If they keep trying to get the fans to their ballpark without entertaining them, eventually they will run out of fans. If fans are being entertained at a price they are willing to pay they become the new advertisers for the team.

After providing the results of the study to the team I was informed the team was thinking of hiring a small out of state advertising firm to figure out how to better advertise the team as to increase attendance. Again I explained the survey results that the problem is not getting the fans in the stadium, it is to get them "back" to the stadium. I didn't even want to start about the small out of state advertising agency working on a region minor league baseball team with plenty of local advertising agencies in the area. Save that for future research.

\section{REFERENCES}

1. $\quad$ Bowman, J. (1996). "Let me entertain you", American Spectator, 29 (9) 68-70.

2. $\quad$ Bristow, D., \& Sebastian R. (2001). "Holy cow! Wait "til next year! A closer look at the brand loyalty of Chicago Cubs baseball fans", The Journal of Consumer Marketing, 18 (3) 256-276.

3. $\quad$ Elliott, M. (2003). "Europeans just want to have fun", TIME, 162 (4) 76-77.

4. King, P. (2002). "Sports and entertainment becomes crowded playing field", Nation's Restaurant News, 36 (5) 24.

5. $\quad$ Lienert, A. (1998). "Managing in minorville", Management Review, 87 (7) 53-57.

6. McLaughlin, A. (2001). "Fun: New priority for Americans", Christian Science Monitor, 93 (195) 1-2.

7. $\quad$ Samuelson, R. (2001). "Fun ethic vs. work ethic?" Newsweek, 138 (11) 43-45.

8. Sheth, J. and Parvatiyar, A. (1995). "Relationship marketing and consumer marketing: antecedents and consequences", Journal of the Academy of Marketing Science, Fall, 255-271. 